\title{
ANTIBACTERIAL BIODEGRADABLE Mg-Ag ALLOYS
}

\author{
Di Tie ${ }^{1, *}$, Frank Feyerabend ${ }^{1}$, Wolf-Dieter Müller ${ }^{2}$, Ronald Schade ${ }^{3}$, Klaus Liefeith ${ }^{3}$, Karl Ulrich Kainer ${ }^{1}$ \\ and Regine Willumeit ${ }^{1}$ \\ ${ }^{1}$ Institute for Material Research, Helmholtz-Zentrum Geesthacht, Geesthacht, Germany \\ ${ }^{2}$ Dental and Biomaterial Research, Charité Universitaetsmedizin, Berlin, Germany \\ ${ }^{3}$ Institute for Bioprocessing and Analytical Measurement Techniques, Rosenhof, Heilbad Heiligenstadt, Germany
}

\begin{abstract}
The use of magnesium alloys as degradable metals for biomedical applications is a topic of ongoing research and the demand for multifunctional materials is increasing. Hence, binary $\mathrm{Mg}-\mathrm{Ag}$ alloys were designed as implant materials to combine the favourable properties of magnesium with the well-known antibacterial property of silver. In this study, three $\mathrm{Mg}-\mathrm{Ag}$ alloys, $\mathrm{Mg} 2 \mathrm{Ag}, \mathrm{Mg} 4 \mathrm{Ag}$ and $\mathrm{Mg} 6 \mathrm{Ag}$ that contain $1.87 \%, 3.82 \%$ and $6.00 \%$ silver by weight, respectively, were cast and processed with solution (T4) and aging (T6) heat treatment.

The metallurgical analysis and phase identification showed that all alloys contained Mg4Ag as the dominant $\beta$ phase. After heat treatment, the mechanical properties of all $\mathrm{Mg}$-Ag alloys were significantly improved and the corrosion rate was also significantly reduced, due to presence of silver. $\mathrm{Mg}(\mathrm{OH})_{2}$ and $\mathrm{MgO}$ present the main magnesium corrosion products, while $\mathrm{AgCl}$ was found as the corresponding primary silver corrosion product. Immersion tests, under cell culture conditions, demonstrated that the silver content did not significantly shift the $\mathrm{pH}$ and magnesium ion release. In vitro tests, with both primary osteoblasts and cell lines (MG63, RAW 264.7), revealed that Mg-Ag alloys show negligible cytotoxicity and sound cytocompatibility. Antibacterial assays, performed in a dynamic bioreactor system, proved that the alloys reduce the viability of two common pathogenic bacteria, Staphylococcus aureus (DSMZ 20231) and Staphylococcus epidermidis (DSMZ 3269), and the results showed that the killing rate of the alloys against tested bacteria exceeded $90 \%$. In summary, biodegradable Mg-Ag alloys are cytocompatible materials with adjustable mechanical and corrosion properties and show promising antibacterial activity, which indicates their potential as antibacterial biodegradable implant materials.
\end{abstract}

Keywords: Magnesium; silver; antibacterial; biodegradable; mechanical properties; corrosion; cytocompatibility.

*Address for correspondence:

Di Tie

Institute for Material Research

Helmholtz-Zentrum Geesthacht, Max-Planck-Str. 1

Geesthacht 21502, Germany

Telephone Number: +494152872503

FAX Number: +49 4152871356.

E-mail: tie-di@hotmail.com

\section{Introduction}

Magnesium-based biodegradable alloys are experiencing a great interest as implant materials suitable for bone and cardiovascular applications (Staiger et al., 2006; Erbel et al., 2007; Witte et al., 2008; Hort et al., 2010; Pollock, 2010; Witte, 2010; Huehnerschulte et al., 2012). They show good cytocompatibility (Witte et al., 2006; Witte et al., 2007) and similar mechanical properties to bone (Witte et al., 2008). Implants made of magnesium alloys provide initially stable and load-bearing materials that are expected to degrade fully in vivo, eliminating the need for a second operation for implant removal (Banovetz et al., 1996). However, although there has been a great effort to optimise the performance of these materials (Xin et al., 2009; Zberg et al., 2009; Wong et al., 2010), the adjustment of the corrosion rate is still the main obstacle on the way to medical application (Zeng et al., 2008). New magnesium based-materials, such as LAE (lithium/ aluminium/ rare earth elements) and WE (yttrium/rare earth elements) alloys, have improved the corrosion and mechanical properties (Drynda et al., 2009; Kirkland et al., 2010; Zhang et al., 2010), but aluminium (Sorenson et al., 1974). Some rare earth elements may also induce cytotoxicity (Palmer et al., 1987) and especially, in the long run, give unwanted systemic reactions - such as Alzheimer's disease in the case of aluminium (Domingo, 2006). On the other hand, multifunctional biodegradable metals are desired but solutions are still not adequate (Yun et al., 2009). Here, we combine the well-known antibacterial properties of silver with magnesium to generate a new degradable alloy which can solve the infection problem during and after implantation (Atiyeh et al., 2007), while tailoring the alloy's corrosion and mechanical performance.

Compared to the history of silver applied as antibacterial material, magnesium is still a "young" material. In the last 100 years there have been several attempts to use magnesium as a biodegradable implant material (McBride, 1938; Witte, 2010). Over 2,300 years ago, Alexander the Great used silver vessels to store drinking water for his troops in order to treat tropical diseases during the war in India (Silver et al., 2006). The applied formulations of silver kept updating with improvements in technology, from bulk silver to ionic silver - supplemented as silver salts (such as $\mathrm{AgNO}_{3}$ ) - or adsorbed on carrier materials (Silver et al., 2006; KwakyeAwuah et al., 2008) and currently to nanosized (Sintubin et al., 2011) as well as alloyed silver (Sreekumari et al., 2003). Silver keeps a high antibacterial activity in a wide range of chemical states. Moreover, recent studies found 
that silver is also effective in the treatment of some extreme microbes, such as methicillin-resistant Staphylococcus aureus (MRSA) and methicillin-resistant Staphylococcus epidermidis (MRSE) - that are famous 'superbugs' that cannot be killed by most antibiotics (Nanda et al., 2009; Saravanana et al., 2010). The latest progress on silver coatings and magnesium-silver alloys for antibacterial application showed satisfactory results as well (Paton et al., 2010; Huang et al., 2011; Necula et al., 2011), while metallic and alloyed silver did not show any cytotoxicity in silver-containing medical devices (Bosetti et al., 2002). A small amount of silver content in alloys or coatings was also reported to improve cytocompatibility and cell viability (Bosetti et al., 2002; Hardes et al., 2007).

The first reported research of manufacturing $\mathrm{Mg}-\mathrm{Ag}$ alloys can be traced back to 1906 (Zemczuznyj, 1906). In the following decades, a number of studies focused on this system for electronic and hydrogen storage applications (Zworykin et al., 1941; Fox, 1946). In the past few years, some attempts to combine elementary silver with a magnesium surface by nanocoating technology also made progress (Loveless et al., 2009). Different from the aforementioned studies, the present work is based on an originally designed binary alloy system in the form of a magnesium-rich alloy for medical applications.

In this paper, the metallurgical microstructure of and heat treatment effects on three $\mathrm{Mg}-\mathrm{Ag}$ alloys were analysed and their mechanical properties were measured at human body temperature $\left(37.0{ }^{\circ} \mathrm{C}\right)$ and compared to pure magnesium. Corrosion properties of the alloys were evaluated under cell culture conditions, by the mini-cellsystem (MCS) (Mueller et al., 2009) and multiple analysis methods were employed to reveal the corrosion product components as well as the ion release. The cytotoxicity and cytocompatibility was determined using cell viability assays that are suitable for magnesium materials (Fischer et al., 2011). The antibacterial activity was measured in a bioreactor with a co-culture of several pathogenic bacteria and in situ microscopy (Frant et al., 2006) to ensure credible results. Based on these results, the suitability of these new alloys as antibacterial biodegradable materials was shown.

\section{Materials and Methods}

\section{Material production and heat treatment}

Three magnesium-silver alloys were studied: $\mathrm{Mg} 2 \mathrm{Ag}$, $\mathrm{Mg} 4 \mathrm{Ag}$ and $\mathrm{Mg} 6 \mathrm{Ag}$, which were cast by adding $2 \%$, $4 \%$ and $6 \%$ silver ( $99.99 \%$, Sigma-Aldrich, Steinheim, Germany) by weight, respectively, into pure magnesium (>99.98 \%, Hydro Magnesium, Oslo, Norway). The composition of the alloys was obtained by X-ray fluorescence (XRF) analysis (Bruker AXS S4 Explorer; Bruker AXS, Karlsruhe, Germany) with Bruker AXS SPECTRA plus software (version 1.70). The density of the alloys was determined by Archimedean principle. For comparison, pure magnesium was used. All materials were prepared by permanent mould casting and then treated by a solidification cooling process. Magnesium and silver were melted in a steel crucible under a protective atmosphere
$\left(\mathrm{Ar}+2 \% \mathrm{SF}_{6}\right)$ at a temperature of $750{ }^{\circ} \mathrm{C}$ for $1.5 \mathrm{~h}$. Then, the melt was stirred for $30 \mathrm{~min}$ at $200 \mathrm{rpm}$, prior to casting the material into a preheated mould $\left(550{ }^{\circ} \mathrm{C}\right)$ made out of mild steel. To assure cleanliness of the cast ingots, a filter (Foseco SIVEX F; Foseco, Borken, Germany) was used. The filled mould was held at $670{ }^{\circ} \mathrm{C}$ for $1 \mathrm{~h}$ under the protective atmosphere. Then, the whole steel crucible with the melt was immersed at $10 \mathrm{~mm} / \mathrm{s}$ into continuous cooling water. As soon as the liquid level of the inside melt was in alignment with the height of outside water, the solidification process was finished.

Solution treatment (T4) of the materials was carried out at $440{ }^{\circ} \mathrm{C}$ for $16 \mathrm{~h}$ under an argon atmosphere, followed by water quenching at $25^{\circ} \mathrm{C}$. Ageing treatment (T6) of the solution-treated samples was performed at $185^{\circ} \mathrm{C}$ for $8 \mathrm{~h}$, also followed by water quenching at $25^{\circ} \mathrm{C}$. Afterwards, the cast and heat-treated ingots were machined to different dimensions for the following measurements.

\section{Microstructural characterisation}

Microscopic characterisation

A scanning electron microscope (SEM, Auriga, Zeiss, Oberkochen, Germany) equipped with an energydispersive X-ray spectrometer (EDX, Sapphire CDU; EDAX International, Mahwah, NJ, USA) was applied to evaluate the composition of the microstructure. $5.0 \mathrm{~mm}$ $\times 20.0 \mathrm{~mm} \times 20.0 \mathrm{~mm}$ brick samples were machined for microstructural characterisations. Measured surfaces were ground in water and ethanol (>99.5\%, Sigma-Aldrich) down to a grinding size of grade 3200 , polished with a lubricant containing $3 \mu \mathrm{m}$ diamond particles $(>99.5 \%$, Sigma-Aldrich), followed by a lubricant containing $1 \mu \mathrm{m}$ diamond particles with the addition of dish liquid (Struers, Willich, Germany). In the last step of polishing, ethanol was used as lubricant instead of water. The specimen were then degreased and rinsed with pure ethanol. SEM analysis was performed shortly after finishing the sample preparation, to characterise the initial conditions. The morphological features were examined by recording secondary electron (SE) images under high vacuum (10$\left.{ }^{6} \mathrm{mbar}\right)$, at $15 \mathrm{kV}$ accelerating voltage, $90 \mu \mathrm{A}$ beam current and $200 \times$ magnification.

\section{$X$-ray diffraction analysis}

Samples were successively polished with emery paper of various grades up to 3200 grade, followed by a diamond suspension down to $1 \mu \mathrm{m}$ diamond particles. Then they were investigated by X-ray diffraction (XRD) in a parallel beam geometry, using $\mathrm{Cu}-\mathrm{K}_{\alpha 1}$ radiation (wavelength $\lambda=0.15406 \mathrm{~nm}$ ). The X-ray diffractometer (Siemens D5000 from Siemens, Munich, Germany) was operated in transmission mode in the range $2 \theta=15-90^{\circ}$ with a step length of $0.0153^{\circ}$ and $3 \mathrm{~s} / \mathrm{step}$. The determination of the lattice parameter had a precision of better than $0.001 \mathrm{~nm}$. Diffraction patterns were analysed using the database PDF-2 (Release 2002) from the International Center for Diffraction (ICDD) (2002).

\section{Mechanical testing}

For the mechanical characterisation of the materials, Vickers hardness (HV5), tension and compression 
measurements were carried out. HV5 measurements were done with a standard micro-hardness tester (Carl Zeiss, Jena, Germany), after machining and mirror polishing, following ASTM standard. The tension and compression tests were performed using a standard mechanical testing machine (Zwick Z050; Zwick, Ulm, Germany). The samples equilibrated for $10 \mathrm{~min}$ at $37.0{ }^{\circ} \mathrm{C}$ before the measurements were started to guarantee a homogenous temperature distribution within the specimens during the tests. All measurements were carried out in quintuplicate to assure statistical accuracy according to the American Society for Testing of Materials (ASTM) standard (ASTM, 2003; ASTM, 2009).

\section{In vitro corrosion testing}

\section{Determination of corrosion rate}

The corrosion rate of the specimen was evaluated by single sweep voltametry, using a mini cell system setup (MCS). The choice of the MCS was made due to the small dimensions of the samples and the need to test the material without any further preparation, to better simulate the clinical conditions (Nascimento et al., 2007). The specimens were $10.0 \mathrm{~mm}$ in diameter and $1.5 \mathrm{~mm}$ in height. As electrolyte, the cell culture medium Dulbecco's Modified Eagle Medium (DMEM) Glutamax-I (Sigma Aldrich Chemie, Taufkirchen, Germany) with the addition of $10 \%$ (by volume) foetal bovine serum (FBS, FBS Gold; PAA Laboratories, Linz, Austria), with a total of $30-45 \mathrm{~g} / \mathrm{L}$ of protein, was used. The detailed description of the formulation can be found elsewhere (Fischer et al., 2010). The MCS was connected to a computer-controlled potentiostat (EI 1286, Schlumberger, Braunschweig, Germany), driven by the software Corrware for Windows (Scribner Associates, Southern Pines, NC, USA). The scan rate was $10 \mathrm{mV} / \mathrm{s}$; the contact area was $0.008 \mathrm{~cm}^{2}$ and the potential range was varied between $-2.0 \mathrm{~V}$ and $-0.5 \mathrm{~V}$ ( $v s$ standard hydrogen electrode, SHE). Measurements were executed at $37.0^{\circ} \mathrm{C}$, under an atmosphere with $5 \% \mathrm{CO}_{2}$, to maintain the data comparability to immersion test results and cell culture conditions. The data were collected and analysed by using the Corrware and Corrview software (Scribner Associates), respectively.

\section{Identification of corrosion products}

X-ray induced photoelectron spectroscopy (XPS) experiments were carried out for identification corrosion products on a Kratos Axis Ultra DLD (Kratos Analytical, Manchester, UK) attached with a $15 \mathrm{kV}$ X-ray gun, using monochromatic $\mathrm{Al} \mathrm{K}_{\alpha}$ radiation. The spot size was $700 \times 300 \mu \mathrm{m}$ and the pass energy was $40 \mathrm{eV}$ for the region measurements and $160 \mathrm{eV}$ for survey scans. As a result of the nonconductive properties of the corrosion products, a charge neutraliser was used to correct the chemical shifts caused by charging. Due to physical limits, the information depth is limited to approx. $5 \mathrm{~nm}$. The following core energy levels were analysed besides survey spectra: $\mathrm{Mg}$ 2p, O 1s, Cl 2p, Ca 2p, P 2p and Ag 3d. By determination of the binding energy of these states, the present chemical bonds were accurately determined. The binding energy (binding energy database, National Institute of Standards and Technology (NIST) Standard Reference Database 20, Version 3.5) can be estimated with an accuracy of $\pm 0.3 \mathrm{eV}$. The curve fitting for chemical composition was performed with Casa 2.3.15 software (Casa Software, Teignmouth, Devon, UK, 2003).

\section{Immersion tests}

After the comparison of the material corrosion properties without and with different heat treatment, T4-treated alloys and pure magnesium as reference were selected for immersion tests to obtain ion release information. The specimens were $10.0 \mathrm{~mm}$ in diameter and $1.5 \mathrm{~mm}$ in height, and successively polished with emery paper of various grades up to 3200 grade followed by a diamond suspension down to $1 \mu \mathrm{m}$ diamond particles. Prior to the corrosion test, the concentration of $\mathrm{Mg}^{2+}$ and $\mathrm{Ag}^{+}$ions $\left(\mathrm{Mg}^{2+}\right.$ Ion Selective Electrode WD-35802, detection limit: $10^{-9}-10^{-3} \mathrm{M}$, Oakton Instruments, Vernon Hills, IL, USA and $\mathrm{Ag}^{+}$Ion Selective Electrode HI-4015, detection limit: $10^{-9}-10^{-6} \mathrm{M}$, Hanna Instruments, Woonsocket, RI, USA) as well as the osmolality (Osmomat 030, Gonotec, Berlin, Germany) and the $\mathrm{pH}(\mathrm{pH} / \mathrm{mV}$ meter PH210, Hanna Instruments) of the media was measured. Then the samples were immersed in triplicates in $3.0 \mathrm{~mL}$ of growth medium (DMEM with $10 \% \mathrm{FBS}$ ) and incubated under cell culture conditions $\left(37^{\circ} \mathrm{C}, 20 \% \mathrm{O}_{2}, 5 \% \mathrm{CO}_{2}\right.$, $95 \%$ relative humidity) for $72 \mathrm{~h}$. Then the $\mathrm{Mg}^{2+}$ and $\mathrm{Ag}^{+}$ ion concentrations, the osmolality and $\mathrm{pH}$ of the extract were determined. The corroded specimens were rinsed with deionised water and dried. The morphology of the corrosion surface was determined by SEM (Auriga, Zeiss) in backscatter mode (backscatter detector (BSD), $20 \mathrm{keV}$, $8.5 \mathrm{~mm}$ working distance).

\section{Cytotoxicity and cytocompatibility tests}

Specimen preparation

Cylindrical specimens with a diameter of $10.0 \mathrm{~mm}$ and a height of $1.5 \mathrm{~mm}$ were cut from the T4 treated blocks by electrical discharge machining. The average weight of the specimens was $207.1 \pm 1.5 \mathrm{mg}$ for pure magnesium and 212.0-216.0 $\pm 1.5 \mathrm{mg}$ for $\mathrm{Mg}$-Ag alloys. The specimens were successively polished with emery paper of various grades, up to 3200 grade, followed by a diamond suspension down to $1 \mu \mathrm{m}$ diamond particles. For sterilisation, the samples were sonicated for $20 \mathrm{~min}$ in dry isopropanol, dried and gamma-sterilised at the "In Core Irradiation" (ICI) facility of the Research Reactor FRG-1 (Geesthacht Neutron Facility GeNF, Geesthacht, Germany) with a total dosage of $29 \mathrm{kGy}$.

\section{Cell culture}

The cell lines MG-63 and RAW 264.7 were chosen as model systems to evaluate the cytotoxicity of silver ions, while human osteoblast primary cells were isolated and cultured for cell viability studies on the $\mathrm{Mg}-\mathrm{Ag}$ alloys.

The human osteosarcoma cell line MG-63 was obtained from the European collection of cell cultures (ECACC, Salisbury, UK). The cells were cultured under standard cell culture conditions $\left(37^{\circ} \mathrm{C}, 20 \% \mathrm{O}_{2}, 5 \% \mathrm{CO}_{2}, 95 \%\right.$ $\mathrm{rH}$ ) in DMEM with $10 \%$ FBS. Cells were passaged at 
subconfluency (70-80\%) and reseeded at a density of $2 \times 10^{4}$ cells $\cdot \mathrm{cm}^{-2}$. For cell culture experiments, cells after the fifth passage were used.

The tumour-derived mouse macrophage cell line (RAW 264.7, ECACC, Salisbury, UK) were cultured in DMEM low glucose (Sigma Aldrich Chemie, Taufkirchen, Germany) with $2 \mathrm{mM}$ glutamine and $10 \% \mathrm{FBS}$ and passaged at $60-70 \%$ confluence. Cells starting from the fifth passage were used for experiments.

Primary human osteoblasts were cultured from bone chips, obtained from patients undergoing total hip arthroplasty. The cancellous bone was cut into $5 \mathrm{~mm}$ thick pieces, and after removal of bone marrow, the bone chips were cultured in DMEM with $10 \%$ FBS. The culture was maintained for approximately 10 days without medium change. Thereafter, the medium was changed every three days and cells were passaged after reaching 70-80\% confluency.

\section{Cytotoxicity of silver ions}

$1 \mathrm{nM}$ to $100 \mathrm{mM} \mathrm{AgNO}_{3}$ (Sigma Aldrich Chemie) was applied as silver ion provider for the measurement of silver ion cytotoxicity. The MG-63 and RAW 264.7 cells were seeded on 96 -well-plates (5,000 cells per well) with $100 \mu \mathrm{L}$ of the cell type specific medium with according concentration of silver ion. The cells were cultivated for $24 \mathrm{~h}$ under cell culture conditions and their viability was analysed by the MTT (methylthiazolyldiphenyltetrazolium bromide, Sigma Aldrich Chemie) assay. After incubation, $10 \mu \mathrm{L}$ of the MTT-solution $(5 \mathrm{mg} / \mathrm{mL}$ MTT in phosphate buffered saline, PBS) was added. After $5 \mathrm{~h}$ the cells were lysed and the formazan crystals solubilised by adding $100 \mu \mathrm{L}$ solubilisation solution (10\% SDS in $0.01 \mathrm{M} \mathrm{HCl}$, Merck, Darmstadt, Germany), followed by an incubation overnight under cell culture conditions. The solubilised formazan product was photometrically quantified using an ELISA reader (Tecan Sunrise, TECAN Deutschland, Crailsheim, Germany) at $570 \mathrm{~nm}$, with a reference wavelength of $655 \mathrm{~nm}$. The same experiments were performed without cells, to exclude an influence of the salt concentrations on the MTT-assay (negative control). In addition, the same tests were executed with $\mathrm{NaNO}_{3}(\geq 99.0 \%$, Sigma-Aldrich) to determine the influence of nitrate and to monitor the change of osmolarity with increasing nitrate. The experiments gave the lethal concentration LC50, where $50 \%$ of the cells survive.

\section{Cell adhesion testing}

To evaluate the cytocompatibility of the $\mathrm{Mg}-\mathrm{Ag}$ alloys, primary osteoblasts were cultured on the surfaces of pure magnesium and T4 treated alloys. Human osteoblast cells were incubated with a seeding density of ca. $1 \times 10^{5}$ cells per specimen with $10 \mathrm{~mL}$ DMEM $+10 \%$ FBS. Three triplicates were tested for every material. Cell culture medium was changed every $48 \mathrm{~h}$ and the total incubation time was 14 days. The viability of osteoblast cells was then determined using a LIVE/DEAD Viability/Cytotoxicity Kit (Invitrogen, Karlsruhe, Germany), which measures the membrane integrity of cells. A fluorescence microscope (Eclipse Ti-S, Nikon, Düsseldorf, Germany) was utilised to observe and calculate the viability of tested cells. Viable cells show a green fluorescence through the reaction of the acetomethoxy derivate of calcein with intracellular esterase, whereas non-viable cells show red fluorescence due to the diffusion of ethidium homodimer across damaged cell membranes and binding with nucleic acids.

\section{Antibacterial properties \\ Specimen preparation}

Cylindrical specimens with a diameter of $10.0 \mathrm{~mm}$ and a height of $1.5 \mathrm{~mm}$ were cut from the T4 treated alloys. Titanium, glass and pure magnesium specimens of the same size were prepared as reference. The specimens were ground with 1200 and 4000 emery paper, and then polished with $1 \mu \mathrm{m}$ diamond suspension. For a clean surface and sterilisation, all the specimens were immersed in $100 \%$ ethanol in an ultrasonic bath for $10 \mathrm{~min}$. After cleaning and sterilisation, the specimens were stored in $100 \%$ ethanol before tests.

\section{Antibacterial tests in a bioreactor}

The antibacterial properties of the material were determined in a co-culture of two Staphylococcus strains: S. aureus (DSMZ 20231 ) and S. epidermidis (DSMZ 3269) at the ratio of 1:1, using tryptic Soy Yeast Extract medium (Trypticase Soy Broth $30 \mathrm{~g} / \mathrm{L}$, Yeast Extract $3 \mathrm{~g} / \mathrm{L}, \mathrm{pH}$ 7.2, Sigma Aldrich Chemie). Both bacteria were reported to be susceptible to silver salt agent (Rodgers et al., 1997). The bacterial concentration was $107 / \mathrm{mL}$ after mixture. The co-culture was first incubated in the bioreactor with $500 \mathrm{~mL}$ media (dynamic cultivation of bacteria, $37^{\circ} \mathrm{C}$, aerated, sterile conditions, $\mathrm{pH}$ 7.2). The surfaces of the samples were then studied by connecting the bioreactor to the flow chambers that contained one specimen each. Thus, specimens were tested in parallel by flushing the medium containing the bacteria with a flow rate of $0.3 \mathrm{~mL} / \mathrm{min}$ for $15 \mathrm{~h}$ above the sample. Each material was studied in three separate tests.

\section{Quantitative determination of the antibacterial activity and imaging}

Qualitative assessment of antibacterial activity was done by imaging of adhering bacteria with live-dead staining, using Confocal laser scanning microscopy (CLSM, TCS SP2, Leica, Wetzlar, Germany) at $488 \mathrm{~nm}$ wavelength during the run of the bioreactor.

After $15 \mathrm{~h}$, incubation the samples were carefully rinsed with PBS to remove unattached bacteria, and then treated by ultrasonic bath at $20 \mathrm{kHz}$ for $15 \mathrm{~min}$ to collect all the adhering bacteria. By checking sample surfaces by microscopy after ultrasonic treatment, it was ensured that all the originally adherent bacteria were removed by ultrasound and available for following quantitative analysis. Quantitative determination of the number of adhering bacteria and their vitality was carried out by counting with a nucleo-counter (6 duplicate areas per sample and 3 duplicate samples per material) and livedead staining (Live / Dead BacLight ${ }^{\mathrm{TM}}$; Molecular Probes, Eugene, OR, USA). 


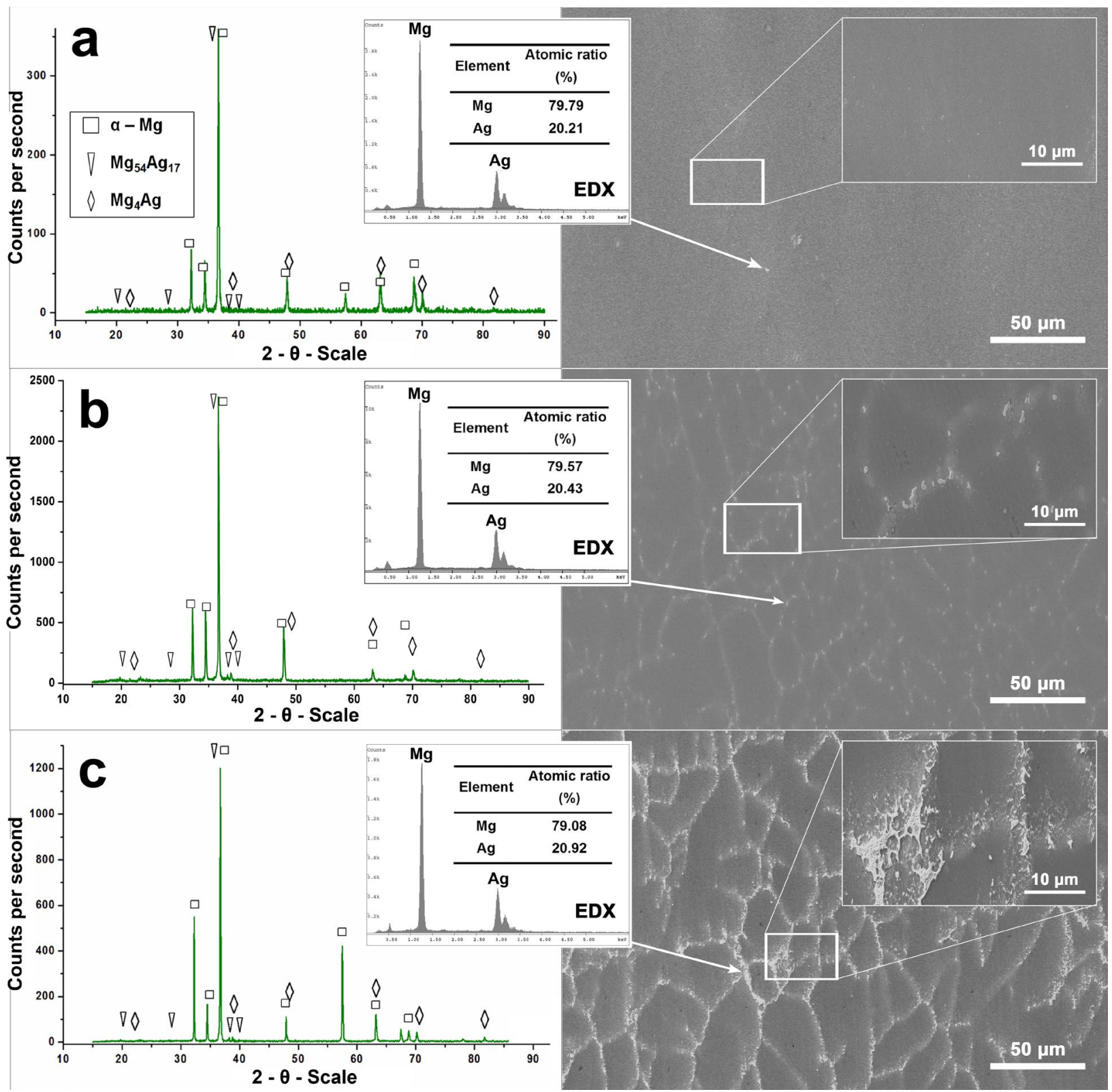

Fig. 1. Microstructure analysis and XRD patterns of cast $\mathrm{Mg} 2 \mathrm{Ag}(\mathbf{a})$, cast $\mathrm{Mg} 4 \mathrm{Ag}(\mathbf{b})$ and cast $\mathrm{Mg} 6 \mathrm{Ag}$ (c) materials. The areas where the EDX analysis took place are indicated in the corresponding SEM images. In all Mg-Ag alloys a combination of $\mathrm{Mg}_{4} \mathrm{Ag}$ and $\mathrm{Mg}_{54} \mathrm{Ag}_{17}$ was identified as the main phases.

\section{Statistical analysis}

Statistics were performed using the SigmaStat package (Systat Software, Erkrath, Germany). Standard analysis comparing more than two treatments was done by using the one-way ANOVA with Holm-Sidak versus control group post-hoc testing. Statistical significance was defined as $p<0.05$, and statistical results are indicated at the relevant experiments.

\section{Results}

Metallurgical microstructure and phase identification Table 1 shows the mass composition, atomic ratio and average density of the studied materials. The microstructure analysis of the cast samples revealed that, with higher silver content, secondary dendrites drastically increase inside the grains (Fig. 1). The average grain size in the cast $\mathrm{Mg} 2 \mathrm{Ag}, \mathrm{Mg} 4 \mathrm{Ag}$ and $\mathrm{Mg} 6 \mathrm{Ag}$ alloys was $600 \mu \mathrm{m}$, $480 \mu \mathrm{m}$ and $350 \mu \mathrm{m}$, respectively. As can be seen in Figs. 1 and 2 , the eutectic of the cast materials, formed during the solidification and distributed along the grain boundaries, were erased by T4 treatment. T4 treatment also wiped out most of the secondary dendrites, which hinted that the solution treatment was successful.

The size of the $\beta$ phase, which was identified by EDX to be $\mathrm{Mg}_{4} \mathrm{Ag}$, varied from hundreds of $\mathrm{nm}$ to several $\mu \mathrm{m}$ for all three cast materials. In the T6 treated samples, a few re-precipitated $\beta$ phases were visible in at $1000 \times$ magnification, while quite few of them were found in the T4 treated samples at the same magnification (Fig. 2).

The X-ray diffraction pattern of the cast alloys, shown in Fig. 1, exhibited dominant $\alpha-\mathrm{Mg}$ reflections. Apart from 


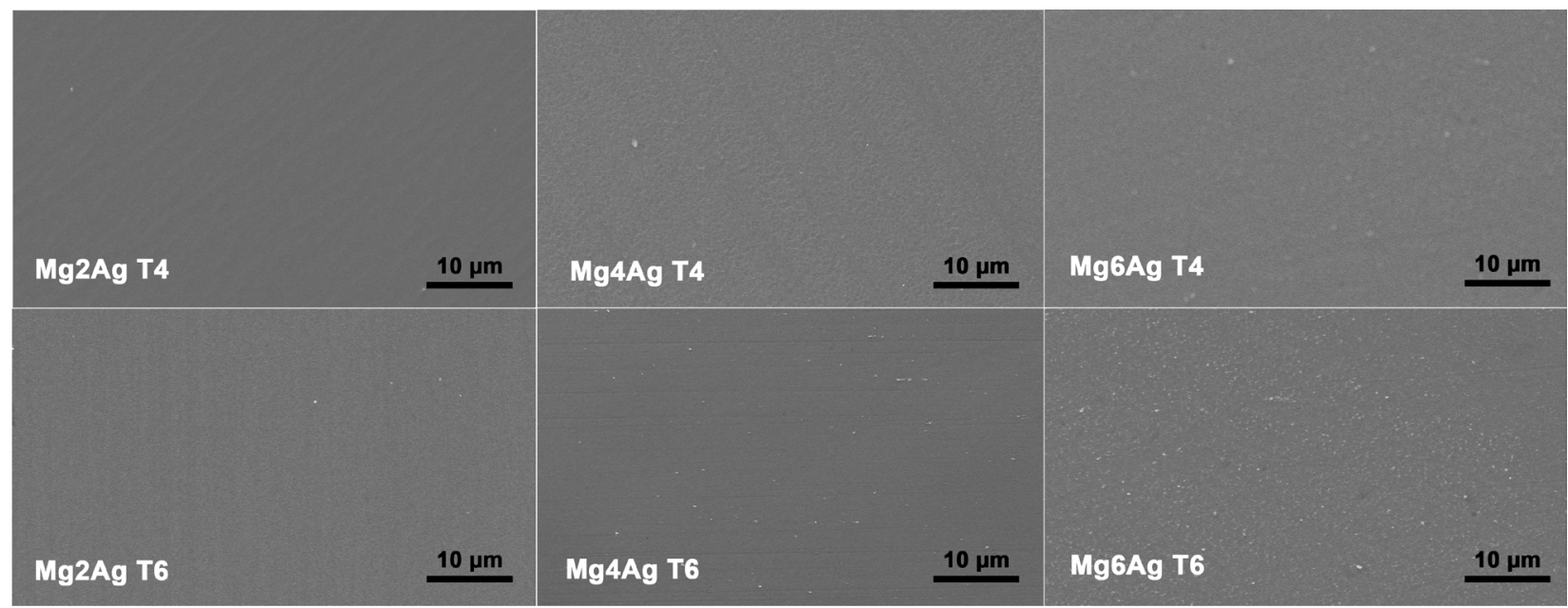

Fig. 2. Microstructure of T4 and T6-treated alloys by electron microscopy.

the $\alpha-\mathrm{Mg}$ phase, there were notable reflections from the $\mathrm{Mg}_{4} \mathrm{Ag}$ phase, which confirmed the phase identification results from EDX analysis. Also, weak indications of $\mathrm{Mg}_{54} \mathrm{Ag}_{17}$ were observed in XRD patterns especially in Mg6Ag.

\section{Mechanical properties}

In Fig. 3, the mechanical properties of the materials are displayed. The average Vickers hardness HV5 of pure magnesium was $27.8 \pm 0.8$. The addition of silver resulted in a significant increase of the average HV5. For cast Mg2Ag, $\mathrm{Mg} 4 \mathrm{Ag}$ and $\mathrm{Mg} 6 \mathrm{Ag}$ values of $32.9 \pm 2.0,35.6 \pm 1.7$ and $35.9 \pm 1.1$, respectively, were found. This can be explained by the increase of $\mathrm{Mg}_{4} \mathrm{Ag} \beta$ phases and dendrite structure regardless of heat treatment status.

T4 treated alloys exhibited a slight decrease in hardness for $\mathrm{Mg} 2 \mathrm{Ag}(30.0 \pm 2.5)$ and $\mathrm{Mg} 4 \mathrm{Ag}$ (34.3 \pm 2.1$)$, while a small increase was found for $\mathrm{Mg} 6 \mathrm{Ag}(40.1 \pm 2.2)$ - which resulted in dissolving of $\beta$ phases. T6 samples had greater hardness values $(40.1 \pm 2.0$ for $\mathrm{Mg} 2 \mathrm{Ag}, 38.8 \pm 0.9$ for $\mathrm{Mg} 4 \mathrm{Ag}$ and $43.3 \pm 1.4$ for $\mathrm{Mg} 6 \mathrm{Ag}$ ) than cast materials because of the re-precipitation of the $\beta$ phases.

Tension and compression values also increased with increasing silver content (Fig. 3, lower row). The ultimate tensile strength (UTS) of the cast Mg6Ag alloy doubled from $108.3 \pm 3.1 \mathrm{MPa}$ (pure $\mathrm{Mg}$ ) to $215.9 \pm 11.3 \mathrm{MPa}$, and the ultimate compressive strength (UCS) changed from $119.0 \pm 1.5 \mathrm{MPa}$ for pure magnesium to $244.1 \pm 9.2 \mathrm{MPa}$ for $\mathrm{Mg} 6 \mathrm{Ag}$. As for the hardness results, T4 and T6 treatment did not influence these parameters.

The Young's modulus and the tensile ductility of the alloys were derived from the stress-strain results. For all materials, the Young's modulus was in the range of
$45 \pm 1 \mathrm{GPa}$, which is roughly double the value for bone. Ductility results demonstrated that the presence of silver provided a notable improvement in tensile ductility, which was most apparent in the cast material and grew from $10.6 \%$ for pure magnesium to $20.0 \%$ for $\mathrm{Mg} 6 \mathrm{Ag}$. After T4 treatment, the average tensile ductility value dropped for $\mathrm{Mg} 6 \mathrm{Ag}$ (from $20.0 \%$ to $18.1 \%$ ), while it grew in $\mathrm{Mg} 2 \mathrm{Ag}$ (from $13.0 \%$ to $15.3 \%$ ). T6 treatment minimised the difference between the alloys' ductility, further leading to $16.0 \%$ for $\mathrm{Mg} 2 \mathrm{Ag}, 16.9 \%$ for $\mathrm{Mg} 4 \mathrm{Ag}$, and $17.4 \%$ for Mg6Ag.

In summary, the mechanical parameters showed that heat-treated $\mathrm{Mg}-\mathrm{Ag}$ alloys exhibited a significant improvement in the mechanical parameter as compared to pure magnesium, while $\mathrm{Mg} 6 \mathrm{Ag}$ was slightly superior to the other materials due to its highest silver content.

\section{Corrosion properties \\ Corrosion rate}

The average corrosion rate of the materials, derived from the single sweep voltammograms, measured in DMEM with $10 \% \mathrm{FBS}$ at $37{ }^{\circ} \mathrm{C}$ and $5 \% \mathrm{CO}_{2}$ are presented in Fig. 4. The highest corrosion rate, exchange current density and lowest polarisation resistance were observed for cast Mg6Ag, which showed a corrosion rate of 1.43 $\mathrm{mm} /$ year. With increasing silver content, $\mathrm{Mg}$-Ag alloys become more susceptible to corrosion regardless of heat treatment status. However, the corrosion properties were significantly improved, especially by $\mathrm{T} 4$ treatment. The lowest degradation was observed for $\mathrm{T} 4$ treated $\mathrm{Mg} 2 \mathrm{Ag}$, which exhibits a corrosion rate of $0.343 \mathrm{~mm} /$ year that is much lower than pure cast magnesium $(0.534 \mathrm{~mm} /$ year$)$. As there was no phase transformation in pure magnesium,

Table 1. Mass composition, atomic ratio and average density of the studied alloys.

\begin{tabular}{|c|c|c|c|}
\hline Material & Mass composition (\%) & Atomic ratio (\%) & Density (g/cm $\mathbf{c}^{\mathbf{3}}$ \\
\hline $\mathrm{Mg}$ & $100 \mathrm{Mg}$ & $100 \mathrm{Mg}$ & 1.74 \\
\hline $\mathrm{Mg} 2 \mathrm{Ag}$ & $98.13 \mathrm{Mg}, 1.87 \mathrm{Ag}$ & $99.56 \mathrm{Mg}, 0.44 \mathrm{Ag}$ & 1.76 \\
\hline $\mathrm{Mg} 4 \mathrm{Ag}$ & $96.18 \mathrm{Mg}, 3.82 \mathrm{Ag}$ & $99.11 \mathrm{Mg}, 0.89 \mathrm{Ag}$ & 1.79 \\
\hline $\mathrm{Mg} 6 \mathrm{Ag}$ & $94.00 \mathrm{Mg}, 6.00 \mathrm{Ag}$ & $98.54 \mathrm{Mg}, 1.46 \mathrm{Ag}$ & 1.83 \\
\hline
\end{tabular}




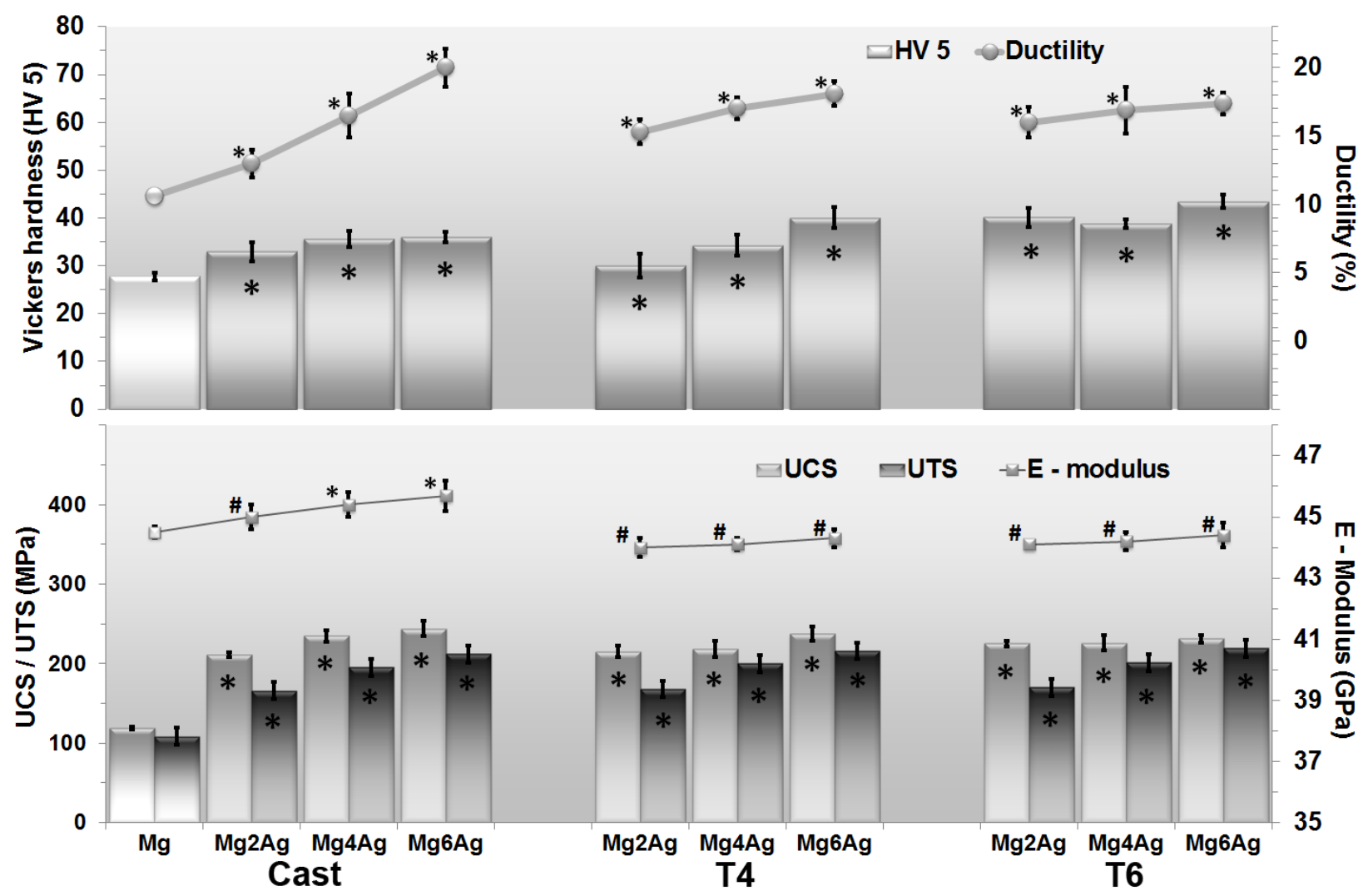

Fig. 3. Summary of the mechanical properties. Upper row: Vickers hardness (HV5) and tensile ductility; lower row: ultimate tensile strength (UTS), ultimate compressive strength (UCS) and Young's modulus. Data from five duplicate samples; mean value \pm standard deviation are shown. The HV5, UTS and UCS values of both cast and heat treated $\mathrm{Mg}-\mathrm{Ag}$ alloys were found to be significantly different (marked by an asterisk * significance level $p<0.05$; \# means no significant difference when compared with pure magnesium).

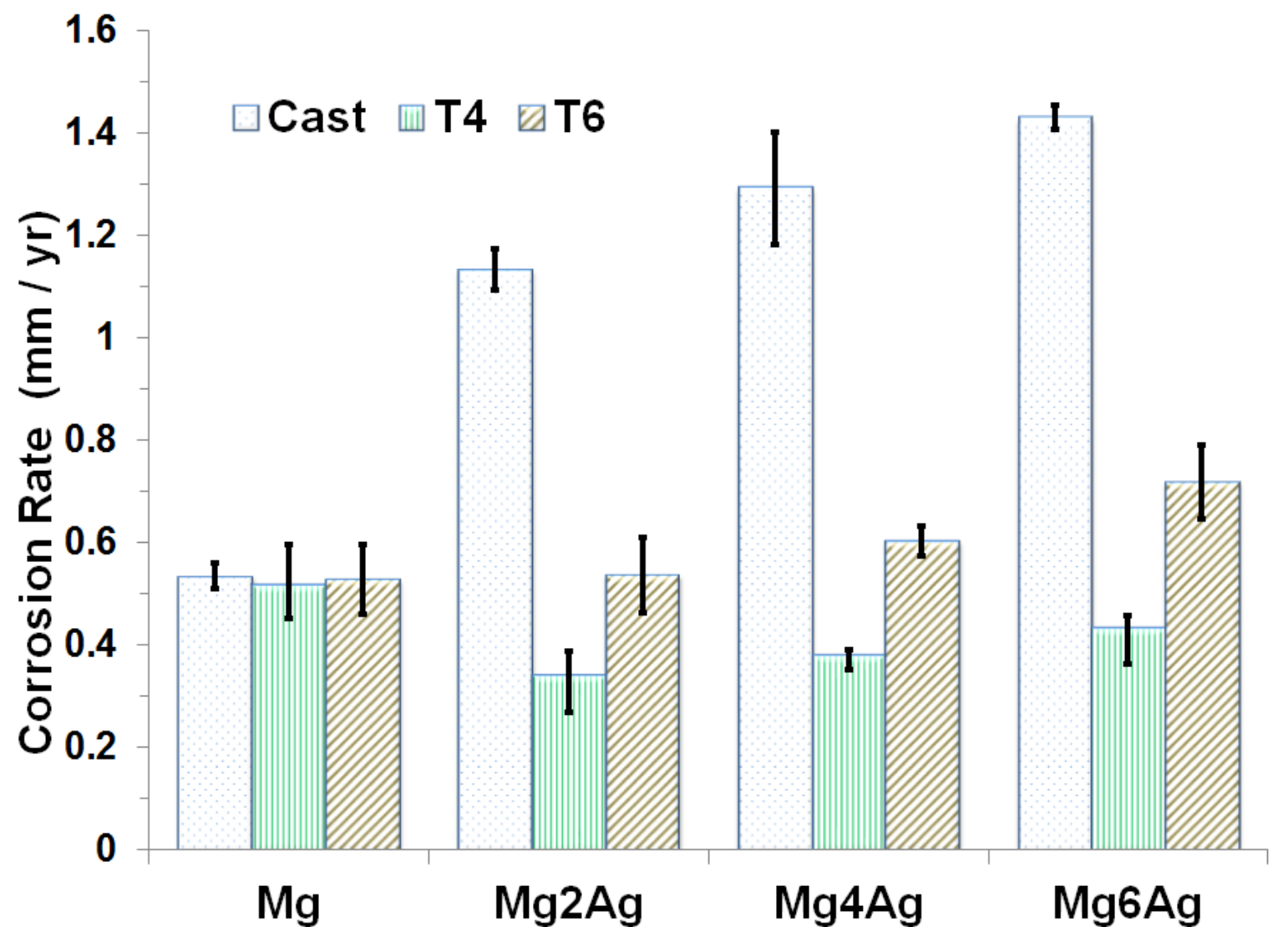

Fig. 4. Corrosion rate of the studied materials by electrochemical analysis (experiment with three individual samples, mean value \pm standard deviation). 

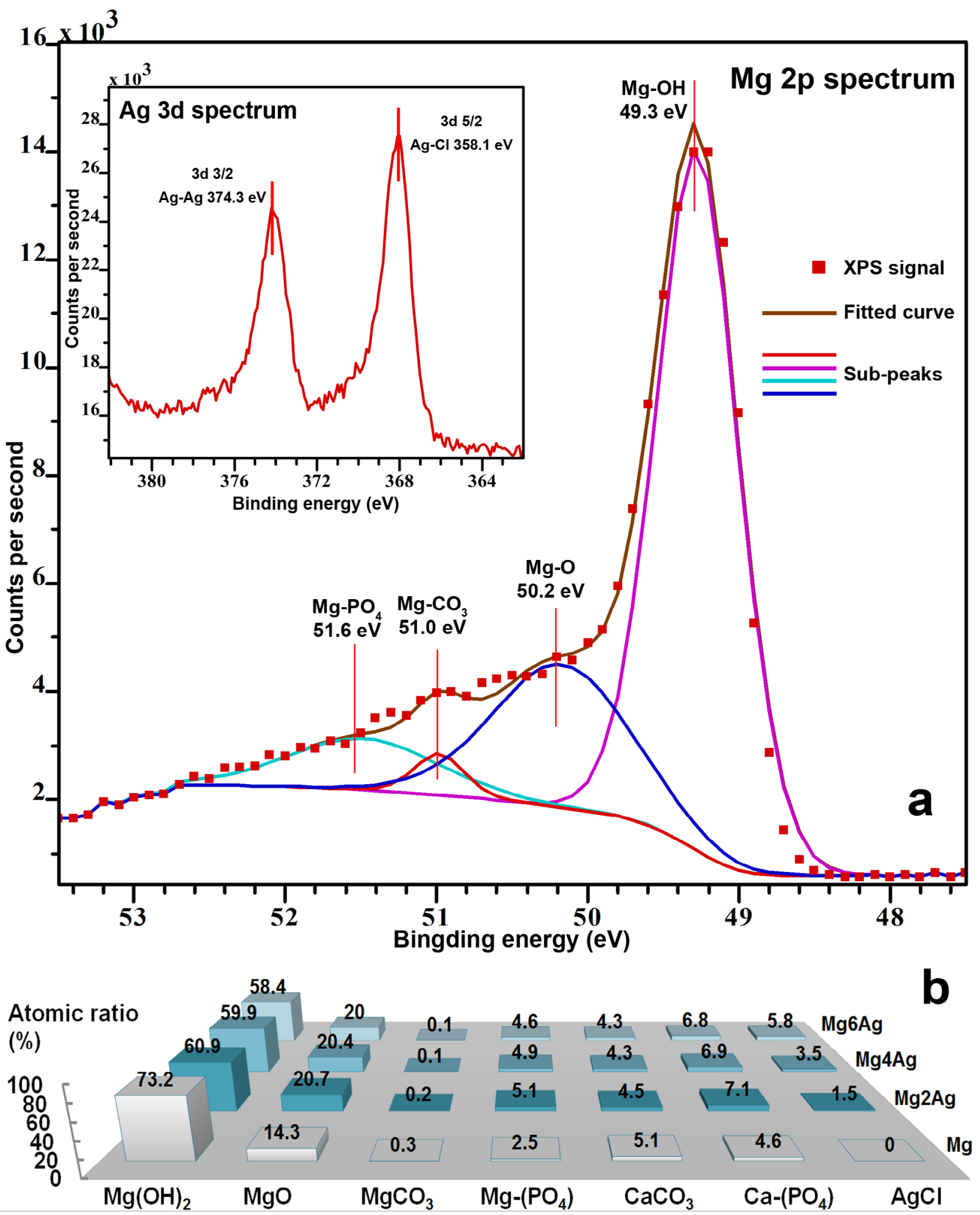

Fig. 5. Composition of the corrosion layer. (a) XPS spectra of $\mathrm{Mg} 2 \mathrm{p}$ and $\mathrm{Ag} 3 \mathrm{~d}$ core energy levels for the corrosion layer of $44 \mathrm{Mg} 2 \mathrm{Ag}$. (b) Compositions of corrosion products counted by $\mathrm{Ca} / \mathrm{Mg}$ atoms in all four T4 treated materials derived from XPS analysis. Data were collected and calculated by XPS area scanning analysis.

its corrosion rate did not vary after T4 heat treatment (from $0.534 \mathrm{~mm} /$ year to $0.519 \mathrm{~mm} /$ year).

From the corrosion point of view, the $\mathrm{T} 4$ treated $\mathrm{Mg} 2 \mathrm{Ag}$ was the best material. However, from a mechanical point of view $\mathrm{Mg} 6 \mathrm{Ag}$ was the most promising material. We consider corrosion to be more crucial. Therefore, we continued the following experiments with $\mathrm{T} 4$ samples only.

\section{Corrosion products analysis}

In order to understand better the corrosion behaviour of the materials under near physiological conditions a detailed composition analysis of the corrosion layer of T4 treated materials was performed.

The compositions of corrosion products of all T4 treated materials were calculated by XPS peak signal 

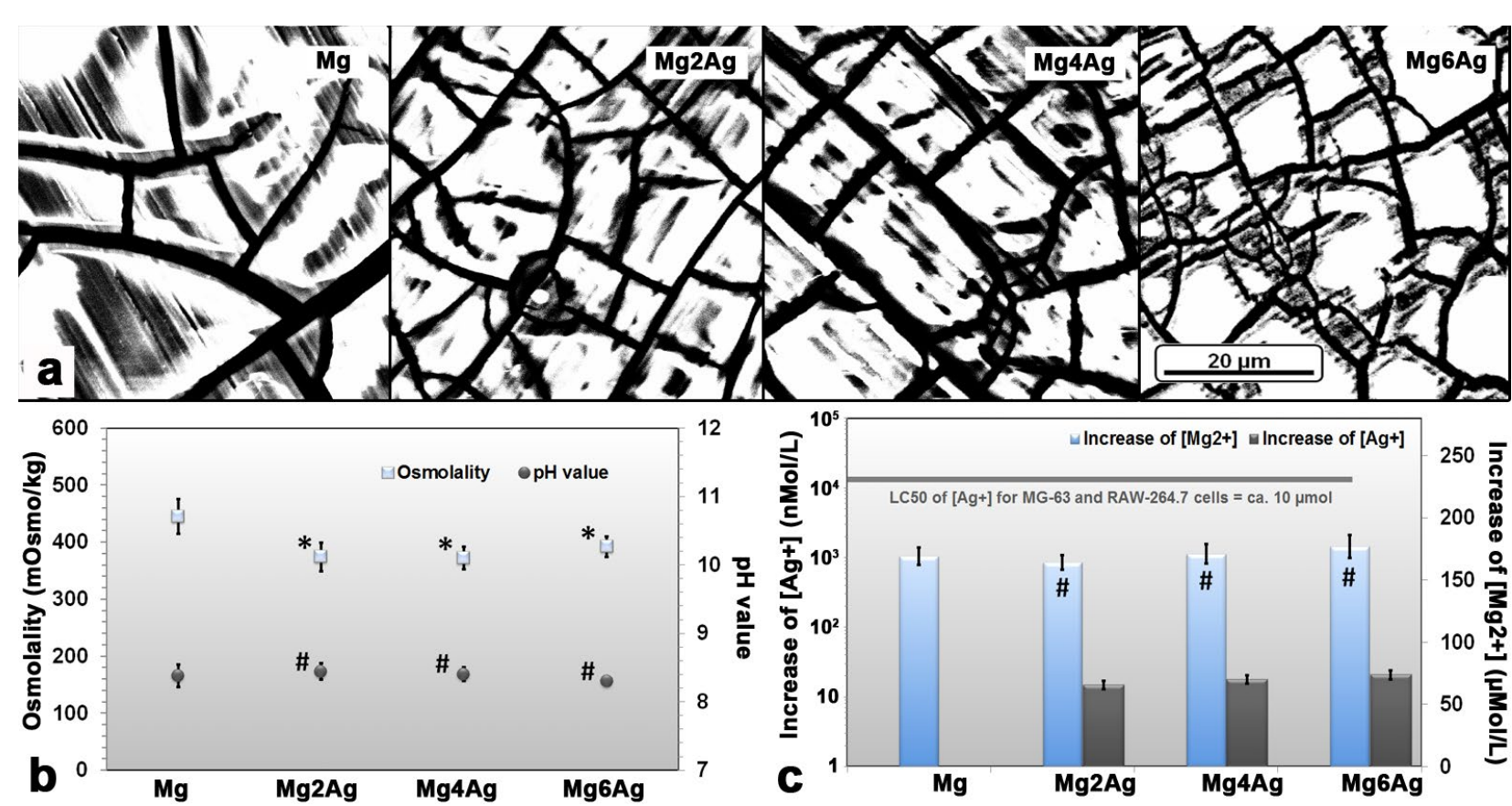

Fig. 6. Overview of the specimen after the immersion test. (a) SEM (BSD) images of the T4 treated samples immersed in DMEM with $10 \% \mathrm{FBS}, 5 \% \mathrm{CO}_{2}$ and at $37^{\circ} \mathrm{C}$ (cell culture conditions) for $72 \mathrm{~h}$. (b) Summary of pH and osmolality values after immersion tests. (c) Changes of $\mathrm{Mg}^{2+}$ and $\mathrm{Ag}^{+}$ion concentration after immersion tests. The experiments were performed in triplicates, and mean value \pm standard deviation is presented. \# means no significant difference, while * means significance level $p<0.05$. The differences in $\mathrm{Mg}^{2+}$ concentration increase between alloys and pure magnesium were not significant. The obtained $\mathrm{Ag}^{+}$concentrations were all far lower than the lethal concentrations (LC50) of MG-63 and RAW 264.7 cells.

integration (Fig. 5b), using the Casa 2.3.15 software. As an example, Fig. 5a shows Mg 2p and Ag 3d XPS spectra of corrosion layer of $\mathrm{T} 4$ treated $\mathrm{Mg} 2 \mathrm{Ag}$. For magnesium corrosion products of all materials, the $\mathrm{Mg} 2 \mathrm{p}$ peak spreads from $47.0 \mathrm{eV}$ to $52.8 \mathrm{eV}$, which can be fitted by $\mathrm{Mg}(\mathrm{OH})_{2}$ at $49.3 \mathrm{eV}$ and $\mathrm{MgO}$ at $50.3 \mathrm{eV}$ (Ardizzone et al., 1997). Besides, $\mathrm{Mg}-\mathrm{CO}_{3}$ and $\mathrm{Mg}-\mathrm{PO}_{4}$ bindings were also present. $\mathrm{AgCl}(386.1 \mathrm{eV})$ as the dominant silver containing corrosion product is present in the corrosion layer of each alloy. With increasing amount of silver, the atomic ratio found in the corrosion layer rises from 1.5 at $\%$ in $\mathrm{Mg} 2 \mathrm{Ag}$ to $5.8 \mathrm{at} \%$ in Mg6Ag. This is a little less than originally found in the alloy. With higher silver content the amount of magnesium-containing products dropped to around $83 \mathrm{at} \%$ in Mg6Ag.

\section{Immersion tests}

The comparison of the corrosion surfaces by SEM (BSD) of the T4 treated samples after immersion tests is depicted in Fig. 6a. The outer corrosion layers of the samples mainly consisted of $\mathrm{MgO} / \mathrm{Mg}(\mathrm{OH})_{2}$ by EDX analysis. Viewed from SEM images, the corrosion product "blocks" on the magnesium surface were bigger than those of the $\mathrm{Mg}-\mathrm{Ag}$ alloys, as a result of finer grain size in alloys than pure magnesium.

The osmolality, $\mathrm{pH}$ and magnesium and silver ion concentration of the corrosion media were measured prior and after the immersion period. The results are exhibited in Fig. $6 \mathrm{~b}$ and c. Low level of silver ion release was observed, which was $10.3 \pm 0.1 \mathrm{nM}$ for $\mathrm{Mg} 2 \mathrm{Ag}, 10.5 \pm 0.1 \mathrm{nM}$ for
$\mathrm{Mg} 4 \mathrm{Ag}$ and $11.0 \pm 0.2 \mathrm{nM}$ for $\mathrm{Mg} 6 \mathrm{Ag}$. The value of $\mathrm{pH}$ and increase in magnesium ion concentration of the media after immersion with alloys were quite similar to the corresponding value for pure magnesium, while the osmolality value decreased compared to pure magnesium, which hinted the total ion release was reduced with presence of silver content.

\section{Cytotoxicity and cytocompatibility}

Silver nitrate $\left(\mathrm{AgNO}_{3}\right)$ ranging in concentrations from $1 \mathrm{nM}$ up to $100 \mathrm{mM}$ was used to examine the possible cytotoxicity of silver to osteoblast like cells MG63 and mouse macrophages RAW 264.7. The viability of the cells, which was analysed by an MTT assay was calculated as per cent of control group ( $n=16$ for each concentration). The LC50 was found to be $11.0 \mu \mathrm{M}$ for MG-63 and $9.0 \mu \mathrm{M}$ for macrophages RAW 264.7 (Fig. 7b). In a control experiment, the presence of $\mathrm{NaNO}_{3}$ showed no influence on cell viability, which proved that the cytotoxicity results only reflect the cellular response to silver ions.

A long-term cytotoxicity and cell adhesion test over 14 days, where human osteoblasts were grown directly on the specimen (Fig. 7a), showed survival rates between $95 \%$ and nearly $100 \%$ (on Mg2Ag). Recalculating the silver ion release results from the immersion tests (Fig. 6c), we found ca. $10 \mathrm{nM}$ silver ion concentrations in media, which is several orders of magnitude lower than the LC50 of MG-63 and RAW 264.7 cells. From this point of view, T4-treated $\mathrm{Mg}-\mathrm{Ag}$ alloys can be considered to be non-cytotoxic. 

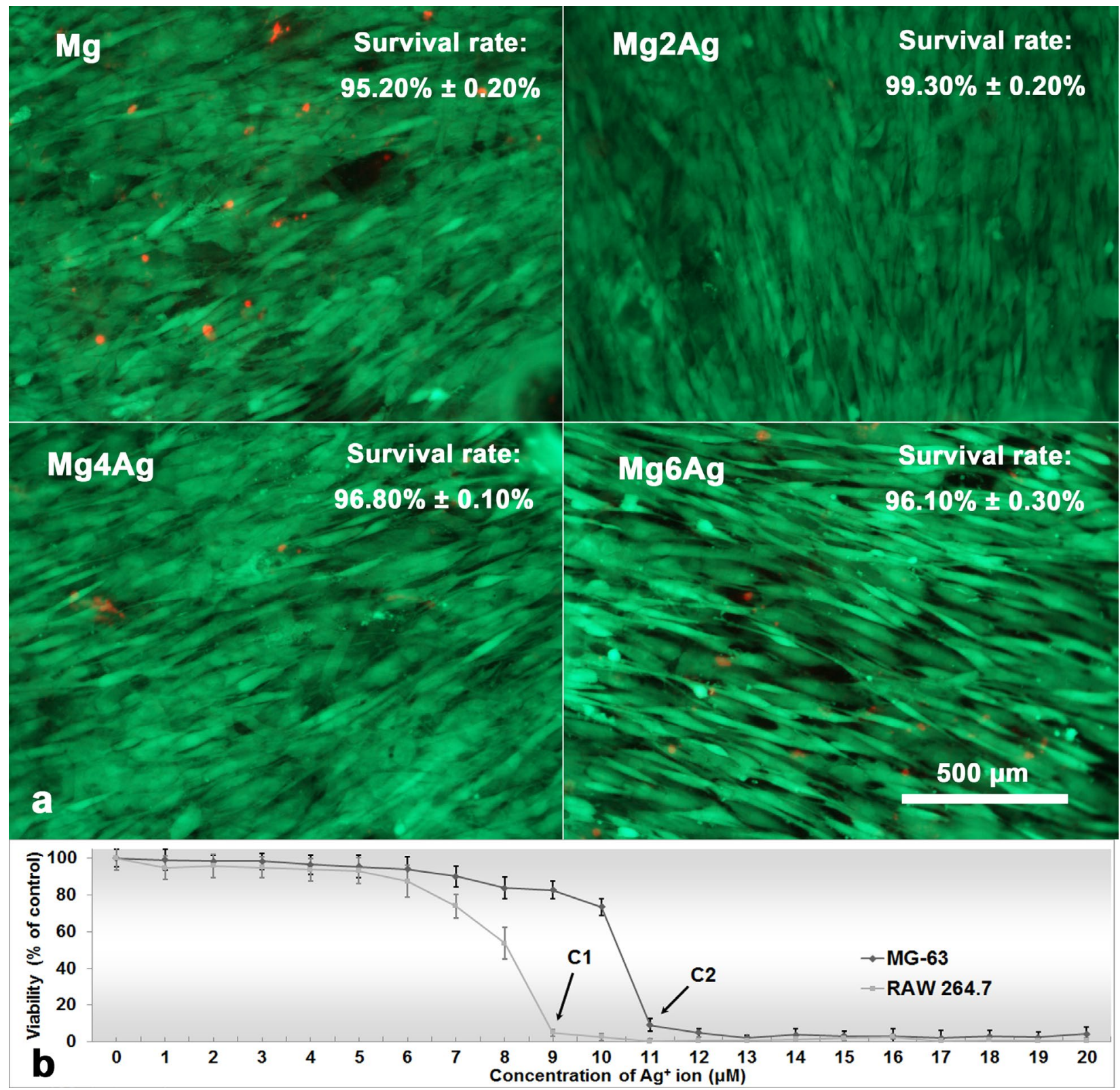

Fig. 7. Summary of biocompatibility and cytotoxicity tests. (a) Fluorescent microscope images and survival rates of human osteoblasts after $72 \mathrm{~h}$ incubation on the materials. Cells were stained with a LIVE/DEAD cell assay, where living cells are labelled green and dead cells red. (b) By MTT viability tests the LC50 was determined to be $11.0 \mu \mathrm{M}$ (C2) for MG-63 cells and 9.0 $\mu \mathrm{M}(\mathrm{C} 1)$ for RAW 264.7 cells. MTT tests were performed in 16 duplicates, and mean value \pm standard deviation is presented.

\section{Antibacterial properties}

To analyse if the silver content was sufficient to have an antibacterial effect, the amount of adhering bacteria and their vitality on $\mathrm{T} 4$ treated $\mathrm{Mg}-\mathrm{Ag}$ alloys was compared with the corresponding values on $\mathrm{Ti}$, glass and pure magnesium. The viability of the bacteria was calculated as per cent of the total adhering amount. The average values for viable bacteria obtained on titanium, glass, magnesium, $\mathrm{Mg} 2 \mathrm{Ag}, \mathrm{Mg} 4 \mathrm{Ag}$ and $\mathrm{Mg} 6 \mathrm{Ag}$ were $49.8 \%$, $52.2 \%, 36.0 \%, 27.5 \%, 21.4 \%$ and $16.5 \%$, respectively. All the alloys' killing rate to tested bacteria was beyond $90 \%$ (Fig. 8b). Compared to the two permanent implant materials, titanium and glass, $\mathrm{Mg}-\mathrm{Ag}$ alloys showed a
50-75 \% reduction of adherent bacteria and a 74-79\% reduction of bacterial viability (Fig. 8b). The tendency of increased antibacterial activity with increased silver atomic ratio in alloys was observed and $\mathrm{Mg} 6 \mathrm{Ag}$ was identified as most potent antibacterial material.

The CLSM micrographs, visualising live/dead stained adherent bacteria on the materials in the bioreactor, are shown in Fig. 8a. The bacterial colonisation was relatively homogenous over the entire sample surface, which ensured representative micrographs. Crystal-like structures were observed on some samples that were generated by corrosion products. Ti and glass samples exhibited little visible influence on bacterial viability, and had smoother 

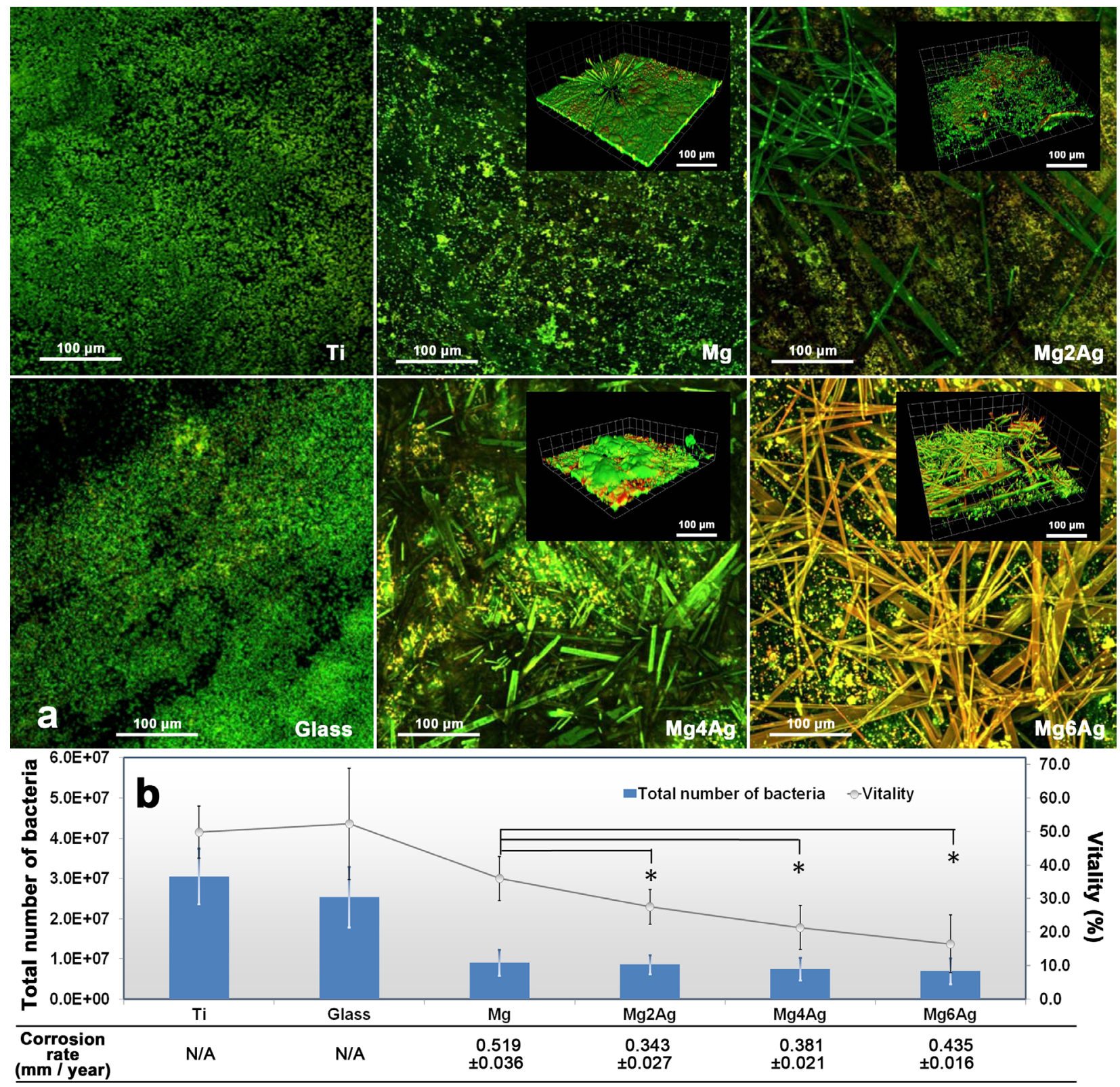

Fig. 8. CLSM images (a) and viability of bacteria (b, mean value \pm standard deviation) on different materials. Bacterial films were fluorescence stained: green colour for living bacteria; red colour for dead bacteria. Crystal structures on alloy surface were generated by corrosion products. The differences in viability of adhering bacteria on alloys and pure magnesium were significant $(*$ significance level $p<0.05)$.

surfaces - due to lack of corrosion. The CLSM patterns also confirmed that the antibacterial activity was correlated with the silver content. Mg6Ag was more effective than $\mathrm{Mg} 4 \mathrm{Ag}$ $>\mathrm{Mg} 2 \mathrm{Ag}>$ magnesium, and all alloys demonstrated far higher antibacterial activity than either glass and titanium.

\section{Discussion}

Degrading Mg-Ag alloys have not yet been used for biomedical applications. Therefore, the newly produced materials had to be characterised for their mechanical and corrosion properties and selective toxicity with respect to bacteria.
A prerequisite to produce materials that give reproducible results is an improved cooling regime at the end of the casting process, which ensures that a grainrefined and purified material is produced (Peng et al., 2010). In general, the addition of Ag leads to improved mechanical properties resulting from the grain refining effect of Ag, leading to small grains of a size between 350$600 \mu \mathrm{m}$ which are much smaller than cast pure magnesium (Fu et al., 2008).

The mechanical performance of T4 treated alloys is attributed to the effects of solution strengthening, while the loss of some mechanical performance is due to dissolving of $\beta$ phases (Braun, 2006). Because the added content of silver did not exceed silver's solubility in magnesium, 
the Young's modulus of Mg-Ag alloys was maintained at a nearly constant level, regardless of composition and heat treatment. The uniform Young's modulus of all tested materials reduces difficulties when choosing suitable materials for specific use for bone applications (Staiger et al., 2006). The Vickers hardness of cortical bone was reported to be about 49.8, which compares quite well with $\mathrm{Mg}-\mathrm{Ag}$ alloys. The T4 and T6 treated $\mathrm{Mg}-\mathrm{Ag}$ alloys also approach the characteristics of natural bone, with an ultimate compressive strength of 130-180 $\mathrm{MPa}$ (Staiger et al., 2006). However, tensile tests show that Mg6Ag has an ultimate tensile strength of almost double the value (220-230 MPa) of cortical bone (Staiger et al., 2006). The mechanical characteristics indicate that heat treated $\mathrm{Mg}-\mathrm{Ag}$ alloys could be suitable as biomaterials for larger degradable implants, especially for load-bearing applications. If needed, further improvement in tensile and compressive strength could be expected by increasing the amount of re-precipitates, which could be achieved by prolonging the aging time. This option extends the application range of $\mathrm{Mg}-\mathrm{Ag}$ alloys and makes them more adjustable for specific needs.

Beside the mechanical parameters, two additional aspects are important: the corrosion of the material, which of course is correlated to the microstructure and its selective antibacterial activity, which should only be caused by the Ag release; and an excessive corrosion rate that results in high $\mathrm{pH}$ values and an intolerable increase of ion concentration in general.

In case of magnesium the corrosion medium is a crucial factor for in vitro corrosion tests (Mueller et al., 2009). To be as close to in vitro conditions as possible, cell culture medium DMEM (supplemented with proteins) was selected (Mueller et al., 2010; Tie et al., 2010). Previous studies reported that the presence of proteins results in a different corrosion behaviour (Williams and Williams, 1988). In this study, FBS was added to the DMEM corrosion media to simulate a more realistic in vivo corrosion environment, and to make the corrosion results more comparable with cytotoxicity tests. Using cell culture medium also introduces a certain buffering capacity and cell culture conditions provided additional effects caused by the presence of oxygen and $\mathrm{CO}_{2}$, as can be seen in the analysis of the corrosion products. The mini-cell system (MCS) employed in this study is based on a mini-cell, which can precisely analyse the electrochemical behaviour of different metallic biomaterials as applied in patients (Mueller et al., 2009).

From the electrochemical results obtained, the following two points are essential: (1) the general corrosion rate increases with increasing silver content; (2) heat treatment dissolved most of silver-enriched dendrites and $\beta$ phases, which resulted in more homogeneous distribution of corrosion potential on the surface, and therefore the corrosion rates of $\mathrm{Mg}-\mathrm{Ag}$ alloys were dramatically reduced (Rao et al., 2003). A dense and continuous surface, achieved by heat treatment, also proved necessary to avoid localised corrosion - since corrosion attacks are mostly started at cracks in the surface layer (Gunde et al., 2009).
The present results proved that T4 heat treatment was needed to acquire acceptable corrosion rates.

The cytocompatibility and antibacterial tests were performed to clarify an important issue to $\mathrm{Mg}-\mathrm{Ag}$ alloys designed as implant materials: to distinguish if a possible cytotoxicity and antibacterial activity is caused by the released $\mathrm{Ag}$ ions or by a general change in $\mathrm{pH}$ and osmolality due to too high corrosion rate. In our studies, the silver ion release was several orders of magnitude lower than the LC50 of MG63 and RAW 264.7 cells. According to literature on cytocompatibility of ionic silver, growth of raw cells are not influenced under the LC50 value we determined (Santoro et al., 2007), and 3T3 fibroblast cell could even survive at concentrations of over $10 \mathrm{mM}$ (Drewa et al., 2007). On the other hand, the amount of released Ag should be high enough to kill bacteria. Pure magnesium also showed antibacterial activity. However, considering its relatively high corrosion rate, some of the effects could be attributed to increasing $\mathrm{pH}$ and osmolality, which could reduce cellular viability as well (Fischer et al., 2011). For the Ag-containing alloys, the corrosion rate is lower than for $\mathrm{Mg}$ and comparable for the three alloys. Still, the antibacterial effect is correlated with the Ag content of the alloys.

Beside a direct toxic action of the released Ag ions, surface properties that could inhibit cell adhesion can be a means to reduce bacterial infections. On the other hand, osteoblast adhesion is an essential requirement for an orthopaedic implant material. The interaction between cells and implant materials are governed by a number of physical and chemical processes, among which surface condition is a major factor (Peššková et al., 2007). The interaction between the alloys and the osteoblasts in this study showed even better cell adhesion and higher cell viability than pure magnesium (Yun et al., 2009). The influence of the composition of the corrosion layers on cell adhesion were not explicitly studied, but will be subject of further studies. It is not yet clear whether proteins adhere to degrading magnesium in the same way as they do to permanent materials (Willumeit et al., 2011). Remnants of proteins were hardly found in the corrosion layer (Tie et $a l ., 2010)$. The presence of silver decreased the corrosion process, while bringing no additional toxicity, which provided a better environment for cell adhesion than pure magnesium. The effects were also proved by the higher seeding density and better range of extension of osteoblasts on $\mathrm{Mg}$-Ag alloys.

The same should be true for bacteria, which would make the material in ideal support for biofilm formation. However, the Mg-Ag alloys exhibited a stronger antibacterial capability than the permanent implant material, titanium, and the biodegradable implant material, pure magnesium. That this can also be attributed to fewer adherent bacteria cannot be excluded, but the CLSM images (Fig. 8a) seem to point in this direction. Compared to the widely used reference materials titanium and glass, $\mathrm{Mg}-\mathrm{Ag}$ alloys reduced both viable bacterial counts (by 50 $75 \%$ ) and bacterial activity (by 74-79\%) significantly (Fig. 8 b). Although the experimental outcomes have already 
proved that the killing rate of $\mathrm{Mg} 6 \mathrm{Ag}$ alloy towards the tested bacteria is even more than $92 \%$ (Fig. 8 b), for a future application, the performance of the Ag alloys could still be further optimised by adjusting the composition and heat treatment process.

The accumulation and metabolism of silver in human body is still being studied (Wijnhoven et al., 2009). Some investigations on wound treatment with ionic silver reported that the accumulation and metabolism by skin and hairs was the possible mechanism (Drake et al., 2005). Metallic silver was proven to pose minimal risk to health (Drake et al., 2005), so the silver content utilised in these alloys was safe to the human body - considering their low silver ion release (Fig. 6c). The low cytotoxicity, low ion release and harmonious interaction with cells of $\mathrm{T} 4$ treated Mg-Ag alloys warranted their low risk when used as implant materials especially when compared with other heavy metal containing magnesium alloys.

\section{Conclusions}

Our results clearly show that heat-treated $\mathrm{Mg}$-Ag alloys exhibit adjustable improved mechanical, corrosive, cytocompatible and antibacterial properties. In summary, T4 treated $\mathrm{Mg} 2 \mathrm{Ag}$ and $\mathrm{Mg} 4 \mathrm{Ag}$ alloys show the biggest potentials as antibacterial biodegradable materials because they show an excellent balance in their property profile.

\section{Acknowledgments}

The authors wish to sincerely thank: Willi Punessen, Gabriele Salamon, Zhi Wang, Lei Yang, Daniela Lange, Sabine Schubert, Lili Wu and Qiuming Peng for their warm help in the laboratory; Lennart Stutz, Daniel Höche and Daniel Laipple for their caring for the mechanical tests and instrumental analysis; colleagues in the Institute for Bioprocessing and Analytical Measurement Techniques, Heiligenstadt and University Hospital Charité, Berlin for providing experimental instruments and good guidance. Financial support from the CSC council and the Helmholtz Association is gratefully acknowledged.

\section{References}

Ardizzone S, Bianchi CL, Fadoni M, Vercelli B (1997) Magnesium salts and oxide: an XPS overview. Appl Surface Sci 119: 253-259.

ASTM (2003) E92-82: Standard Test Method for Vickers Hardness of Metallic Materials. ASTM, Philadelphia, PA.

ASTM (2009) E8/E8M: Standard Test Methods for Tension Testing of Metallic Materials. ASTM, Philadelphia, PA.

Atiyeh BS, Costagliola M, Hayek SN, Dibo SA (2007) Effect of silver on burn wound infection control and healing: Review of the literature. Burns 33: 139-148.

Banovetz JM, Sharp R, Probe RA, Anglen JO (1996) Titanium plate fixation: A review of implant failures. $\mathrm{J}$ Orthopaed Trauma 10: 389-394.
Bosetti M, Massè A, Tobin E, Cannas M (2002) Silver coated materials for external fixation devices: in vitro biocompatibility and genotoxicity. Biomaterials 23: 887892.

Braun R (2006) Nd:YAG laser butt welding of AA6013 using silicon and magnesium containing filler powders. Mater Sci Eng A Struct Mater Prop Microstruct Proc 426: 250-262.

Domingo JL (2006) Aluminum and other metals in Alzheimer's disease: A review of potential therapy with chelating agents. J Alzheimer's Dis 10: 331-341.

Drake PL, Hazelwood KJ (2005) Exposure-related health effects of silver and silver compounds: A review. Ann Occup Hyg 49: 575-585.

Drewa T, Szmytkowska K, Chaberski M (2007) The short term exposition of $\mathrm{AgNO}_{3}$ on $3 \mathrm{~T} 3$ mouse fibroblast cell line. Acta Pol Pharm 64: 4.

Drynda A, Deinet N, Braun N, Peuster M (2009) Rare earth metals used in biodegradable magnesium-based stents do not interfere with proliferation of smooth muscle cells but do induce the upregulation of inflammatory genes. J Biomed Mater Res 91A: 360-369.

Erbel R, Di Mario C, Bartunek J, Bonnier J, de Bruyne B, Eberli FR, Erne P, Haude M, Heublein B, Horrigan M, Ilsley C, Bose D, Koolen J, Luscher TF, Weissman $\mathrm{N}$, Waksman R, PROGRESS-AMS Investigators (2007) Temporary scaffolding of coronary arteries with bioabsorbable magnesium stents: a prospective, nonrandomised multicentre trial. Lancet 369: 1869-1875.

Fischer J, Prosenc MH, Wolff M, Hort N, Willumeit R, Feyerabend F (2010) Interference of magnesium corrosion with tetrazolium-based cytotoxicity assays. Acta Biomaterialia 6: 1813-1823.

Fischer J, Profrock D, Hort N, Willumeit R, Feyerabend F (2011) Improved cytotoxicity testing of magnesium materials. Materi Sci Eng B Adv Funct Solid-State Mater 176: $830-834$.

Fox FA (1946) Equilibrium relations and some properties of magnesium lithium and magnesium silver lithium alloys. J Inst Metals 72: 540-542.

Frant M, Stenstad P, Johnsen H, Dölling K, Rothe U, Schmid R, Liefeith K (2006) Anti-infective surfaces based on tetraether lipids for peritoneal dialysis catheter systems. Materialwiss Werkstofftech 37: 538-545.

Fu HM, Qiu D, Zhang MX, Wang H, Kelly PM, Taylor JA (2008) The development of a new grain refiner for magnesium alloys using the edge-to-edge model. J Alloys Compounds 456: 390-394.

Gunde P, Uggowitzer PJ (2009) In vitro Degradation of a Magnesium Alloy in Simulated Body Fluid: Influence of Heat Treatment and Plastic Deformation. Eur Cell Mater 17 Supp 1: 17.

Hardes J, Streitburger A, Ahrens H, Nusselt T, Gebert C, Winkelmann W, Battmann A, Gosheger G (2007) The influence of elementary silver versus titanium on osteoblast behaviour in vitro using human osteosarcoma cell lines. Sarcoma 2007: 26539.

Hort N, Huang Y, Fechner D, Störmer M, Blawert C, Witte F, Vogt C, Drücker H, Willumeit R, Kainer KU, Feyerabend F (2010) Magnesium alloys as implant 
materials - Principles of property design for Mg-RE alloys. Acta Biomaterialia 6: 1714-1725.

Huang CF, Chiang HJ, Lan WC, Chou HH, Ou KL, $\mathrm{Yu} \mathrm{CH}$ (2011) Development of silver-containing austenite antibacterial stainless steels for biomedical applications Part I: microstructure characteristics, mechanical properties and antibacterial mechanisms. Biofouling 27: 449-457.

Huehnerschulte T, Reifenrath J, von Rechenberg B, Dziuba D, Seitz J, Bormann D, Windhagen H, MeyerLindenberg A (2012) In vivo assessment of the host reactions to the biodegradation of the two novel magnesium alloys ZEK100 and AX30 in an animal model. BioMed Eng OnLine 11: 14.

International Center for Diffraction Data (ICDD) (2002) The powder diffraction file. www.icdd.com.

Kirkland NT, Lespagnol J, Birbilis N, Staiger MP (2010) A survey of bio-corrosion rates of magnesium alloys. Corr Sci 52: 287-291.

Kwakye-Awuah B, Williams C, Kenward MA, Radecka I (2008) Antimicrobial action and efficiency of silverloaded zeolite X. J Appl Microbiol 104: 1516-1524.

Loveless JD, Alemohammad H, Li J, Gertsman V, Emadi D, Toyserkani E, Esmaeili S (2009) Laser-assisted maskless microdeposition of silver nano-particles on a magnesium substrate. Mater Lett 63: 1397-1400.

McBride ED (1938) Absorbable metal in bone surgery. J Am Med Assoc 111: 7.

Mueller WD, de Mele MFL, Nascimento ML, Zeddies M (2009) Degradation of magnesium and its alloys: Dependence on the composition of the synthetic biological media. J Biomed Mater Res A 90A: 487-495.

Mueller WD, Lucia Nascimento M, Lorenzo de Mele MF (2010) Critical discussion of the results from different corrosion studies of $\mathrm{Mg}$ and $\mathrm{Mg}$ alloys for biomaterial applications. Acta Biomaterialia 6: 1749-1755.

Nanda A, Saravanan M (2009) Biosynthesis of silver nanoparticles from Staphylococcus aureus and its antimicrobial activity against MRSA and MRSE. Nanomed-Nanotechnol Biol Med 5: 452-456.

Nascimento ML, Mueller WD, Carvalho AC, Tomas H (2007) Electrochemical characterization of cobalt-based alloys using the mini-cell system. Dent Mater 23: 369-373.

Necula BS, Apachitei I, Tichelaar FD, Fratila-Apachitei LE, Duszczyk J (2011) An electron microscopical study on the growth of TiO2-Ag antibacterial coatings on $\mathrm{Ti} 6 \mathrm{Al} 7 \mathrm{Nb}$ biomedical alloy. Acta Biomaterialia 7: 2751-2757.

Palmer RJ, Butenhoff JL, Stevens JB (1987) Cytotoxicity of the rare earth metals cerium, lanthanum, and neodymium in vitro: Comparisons with cadmium in a pulmonary macrophage primary culture system. Environm Res 43: 142-156.

Paton BE, Kaleko DM, Koval YM, Slipchenko VM, Musienko RY, Neganov LM, Odnosum VV, Sych TG (2010) Influence of alloying with silver and tantalum on features of medical-purpose Ti-Ni alloy. Metallofiz Nov Tekhnol-Met Phys Adv Techn 32: 1691-1703.

Peng QM, Huang YD, Zhou L, Hort N, Kainer KU (2010) Preparation and properties of high purity Mg-Y biomaterials. Biomaterials 31: 398-403.
Peššková V, Kubies D, Hulejová H, Himmlová L (2007) The influence of implant surface properties on cell adhesion and proliferation. J Mater Sci: Mater Med 18: 465-473.

Pollock TM (2010) Weight loss with magnesium alloys. Science 328: 986-987.

Rao RVS, Wolff U, Baunack S, Eckert J, Gebert A (2003) Corrosion behaviour of the amorphous Mg65Y10Cu15Ag10 alloy. Corr Sci 45: 817-832.

Rodgers GL, Mortensen JE, Fisher MC, Long SS (1997) In vitro susceptibility testing of topical antimicrobial agents used in pediatric burn patients: comparison of two methods. J Burn Care Rehabil 18: 406-410.

Santoro C, Duchsherer N, Grainger D (2007) Antimicrobial efficacy and ocular cell toxicity from silver nanoparticles. Nanobiotechnol 3: 55-65.

Saravanana M, Nanda A (2010) Extracellular synthesis of silver bionanoparticles from Aspergillus clavatus and its antimicrobial activity against MRSA and MRSE. Coll Surf B 77: 214-218.

Silver S, Phung LT, Silver G (2006) Silver as biocides in burn and wound dressings and bacterial resistance to silver compounds. J Ind Microbiol Biotechnol 33: 627-634.

Sintubin L, De Gusseme B, Van der Meeren P, Pycke BFG, Verstraete W, Boon N (2011) The antibacterial activity of biogenic silver and its mode of action. Appl Microbiol Biotechnol 91: 153-162.

Sorenson JRJ, Campbell IR, Tepper LB, Lingg RD (1974) Aluminum in the environment and human health. Environ Health Perspect 8: 3-95.

Sreekumari KR, Nandakumar K, Takao K, Kikuchi Y (2003) Silver containing stainless steel as a new outlook to abate bacterial adhesion and microbiologically influenced corrosion. Isij Int 43: 1799-1806.

Staiger MP, Pietak AM, Huadmai J, Dias G (2006) Magnesium and its alloys as orthopedic biomaterials: A review. Biomaterials 27: 1728-1734.

Tie D, Feyerabend F, Hort N, Willumeit R, Hoeche D (2010) XPS studies of magnesium surfaces after exposure to Dulbecco's Modified Eagle Medium, Hank's Buffered Salt Solution, and Simulated Body Fluid. Adv Eng Mater 12: B699-B704.

Wijnhoven SWP, Peijnenburg WJGM, Herberts CA, Hagens WI, Oomen AG, Heugens EHW, Roszek B, Bisschops J, Gosens I, Van De Meent D, Dekkers S, De Jong WH, Van Zijverden M, Sips AJAM, Geertsma RE (2009) Nano-silver - a review of available data and knowledge gaps in human and environmental risk assessment. Nanotoxicology 3: 109-138.

Williams RL, Williams DF (1988) Albumin adsorption on metal surfaces. Biomaterials 9: 206-212.

Willumeit R, Fischer J, Feyerabend F, Hort N, Bismayer U, Heidrich S, Mihailova B (2011) Chemical surface alteration of biodegradable magnesium exposed to corrosion media. Acta Biomaterialia 7: 2704-2715.

Witte F (2010) The history of biodegradable magnesium implants: A review. Acta Biomaterialia 6: 1680-1692.

Witte F, Fischer J, Nellesen J, Crostack HA, Kaese V, Pisch A, Beckmann F, Windhagen H (2006) In vitro and in vivo corrosion measurements of magnesium alloys. Biomaterials 27: 1013-1018. 
Witte F, Feyerabend F, Maier P, Fischer J, Stormer M, Blawert C, Dietzel W, Hort N (2007) Biodegradable magnesium-hydroxyapatite metal matrix composites. Biomaterials 28: 2163-2174.

Witte F, Hort N, Vogt C, Cohen S, Kainer KU, Willumeit R, Feyerabend F (2008) Degradable biomaterials based on magnesium corrosion. Curr Opin Solid State Mater Sci 12: 63-72.

Wong HM, Yeung KWK, Lam KO, Tam V, Chu PK, Luk KDK, Cheung KMC (2010) A biodegradable polymerbased coating to control the performance of magnesium alloy orthopaedic implants. Biomaterials 31: 2084-2096.

Xin YC, Jiang J, Huo KF, Tang GY, Tian XB, Chu PK (2009) Corrosion resistance and cytocompatibility of biodegradable surgical magnesium alloy coated with hydrogenated amorphous silicon. J Biomed Mater Res A 89A: 717-726.

Yun YH, Dong ZY, Lee N, Liu YJ, Xue DC, Guo XF, Kuhlmann J, Doepke A, Halsall HB, Heineman W, Sundaramurthy S, Schulz MJ, Yin ZZ, Shanov V, Hurd D, Nagy P, Li WF, Fox C (2009) Revolutionizing biodegradable metals. Mater Today 12: 22-32.

Zberg B, Uggowitzer PJ, Loffler JF (2009) MgZnCa glasses without clinically observable hydrogen evolution for biodegradable implants. Nat Mater 8: 887-891.

Zemczuznyj SF (1906) On the alloys of magnesium with silver. Z Anorg Chem 49: 400-414.

Zeng RC, Dietzel W, Witte F, Hort N, Blawert C (2008) Progress and challenge for magnesium alloys as biomaterials. Adv Eng Mater 10: B3-B14.

Zhang S, Zhang X, Zhao C, Li J, Song Y, Xie C, Tao H, Zhang Y, He Y, Jiang Y, Bian Y (2010) Research on an Mg$\mathrm{Zn}$ alloy as a degradable biomaterial. Acta Biomaterialia 6: 626-640.

Zworykin VK, Ruedy JE, Pike EW (1941) Silvermagnesium alloy as a secondary electron emitting material. J Appl Phys 12: 696-698.

\section{Discussion with Reviewer}

D. Grainger: Why is a co-culture reactor used? Do these strains really appear together in infections? I have never read that. Although the bioreactor is started with both strains, what is the outflow composition? Are the flow rates and volumes involved realistic for the applications aimed for?

Authors: It was described that the amount of S. epidermidis (typical coloniser on human skin) in natural niches decreases if $S$. aureus bacteria (coloniser on mucous surfaces) are present. However, there are some articles about the interactions of Staphylococcus strains in nature (plasmid transfer by close contact, see Forbes and Schaberg, 1983 and McDonell et al., 1983; additional references). A further aspect is represented by findings that show the involvement of $S$. epidermidis specific phenol-soluble modulins (PMAs) on disruptive processes in biofilm formation and structuring (Otto, 2008; additional reference). All of these data indicate a more complex interaction between Staphylococcus strains than so far assumed and justify the use of several Staphylococcus strains for biofilm formation tests with respect of natural conditions on several implant sites.

D. Grainger: Although the bioreactor is started with both strains, what is the outflow composition? Are the flow rates and volumes involved realistic for the applications aimed for?

Authors: The mixed culture of both strains (1:1) is prepared freshly from monocultures in the late logarithmic growth phase directly before starting of each test. The duration of the test is $15 \mathrm{~h}$. The composition of the mixed culture within the vessel and, of course, the flow channel is more or less constant during this incubation period. The flow rate of $0.3 \mathrm{~mL} / \mathrm{min}$ using our flow chambers represents a low shear stress of approximately $0.001 \mathrm{dyne} /$ $\mathrm{cm}^{2}$. This is realistic for implant sites in soft tissues or bone (in contrast to implants like stents in blood vessels with significant higher flow shear stresses). The aim of these in vitro tests was to test bacterial adherence in an early phase of biofilm formation, under physiological situations as far as possible. To detect antimicrobial effects it is necessary to apply appropriate amounts of bacterial cells that allow the quantification of these effects. The used test design has proved to be qualified for quantitative in vitro bacterial adhesion tests.

D. Grainger: What are the clinical applications the authors aim for with this material?

Authors: The clinical applications aimed for have to be seen from two sides: On the one hand, the intention is that the implant material is degraded in the body after the fulfilment of its scaffolding function to avoid the second surgery; on the other hand, an additional antibacterial support will be supplied. The intended use is in the orthopaedic area for non-permanent implants for bone fixation. Although the infection rate here is lower than for permanent implants, it still is a problem. Therefore, an intrinsic antiracial property throughout the degradation process, which is not based on antibiotics but rather complementary, is necessary, especially in cases where open fractures or injuries are present.

\section{Additional References}

Forbes BA, Schaberg DR (1983) Transfer of resistance plasmids from Staphylococcus epidermidis to Staphylococcus aureus: Evidence for conjugative exchange of resistance. J Bacteriol 153: 627-634.

McDonnell RW, Sweeney HM, Cohen S (1983) Conjugational transfer of gentamicin resistance plasmids intra- and interspecifically in Staphylococcus aureus and Staphylococcus epidermidis. Antimicrob Agents Chemother 23: 151-160.

Otto M (2008) Staphylococcal biofilms. Curr Top Microbiol Immunol 322: 207-228. 